\title{
Skill Competency Test Model (UKK) Graduates of Partnership-Based Vocational High School: Preparing Graduates Facing the Fourth Industrial Revolution
}

\author{
Muhammad Rais \\ Education of Agricultural Technology Department \\ Universitas Negeri Makassar \\ Makassar, Indonesia \\ m.rais@unm.ac.id
}

\begin{abstract}
The challenge faced by Indonesian education nowadays is the swift development of industrial revolution that is entering the 4th generation. The education at all levels of the educational units, including Vocational High School (SMK) is continuing to work early preparing itself facing the era of industry 4.0. Improving the quality of graduates becomes an urgent part in preparing excellent human resources in facing the workforce competition, which is characterized by the automation and digitization which happens in welcoming the era of industry 4.0. This article examines the proposed certification test model of Vocational School competence as the reinforcement to the certification test model that has been formulated by the Directorate of Vocational Education. The model which is offered in this study is that the program of the competency certification test should be divided into certification test of expertise as the main skill and the test of computer skill, language competences (English and Mandarin), and soft skill values as supporting competences.
\end{abstract}

Keywords - Skill Competency Test, Partnership Based, Fourth Industrial Revolution

\section{INTRODUCTION}

Education has the main purpose to prepare learners so that their graduates can compete in the society. According to Rousseau [1], after graduated, learners must have the competence of cognitive and psychomotor reasoning in carrying out the work. Vocational education is an institution that prepares its graduates to obtain a job at various levels and to orient to a particular type of work. Vocational High School as one type of vocational education is a service that prepares students to have the ability to work, to be competitive, and to have some particular excellences to be applied in certain workforces according to their expertise.

To measure the aspects indicating whether SMK graduates already have a number of competencies required in the workplace or not, one of the approaches is the competency test. The competency test is a technical and nontechnical assessment process conducted by gathering relevant evidences to determine whether a person is competent or not in a certain competence or qualification unit [2]. Therefore, to achieve certain competencies such as the above concept, we need a process or a competency test method which is relevant to the current era of technological development and competency demands.
One of the indicators indicating SMK graduates to have high competitiveness is that they have competency certification according to their expertise. Through a series of competency tests, SMK graduates can be regarded to have already possessed a number of competencies covering key skills and supporting expertise. The main skills are the ones gained after the learners follow the educational process in the vocational school according to the skills they are focusing on, and ended by studying the vocational theory and vocational practice exam. Supporting expertise is an additional skill that complements the main expertise and provides recommendations stating that graduates with a support expertise are a plus to them. We also affirm that the graduates are ready to compete in the workforce. These support skills can include computer skills, language skills (English and Mandarin) and other soft skills.

\section{Vocational GraduAte In the ERA OF THE Fourth INDUSTRIAL REVOLUTION}

It is undeniable that nowadays, Indonesia's labor competition is getting tighter. Along with that, the demands of labour quality continue to be echoed. The Labor Minister, Dhakiri [3] said that the competitiveness of Indonesian workers must continue to be encouraged to ensure Indonesia is more competitive and outs as the winner. One of the vocational education institutions that produce labours is SMK. As a vocational education, SMK is required to prepare itself to face the era of global competition in order to produce workers who are highly competitive, skilled, and qualifiedly relevant to the demands of the current workplace. Having a number of experts in both key skills and additional expertise demonstrates the responsiveness to the coming of industrial revolution 4.0, an era demonstrating the mastery of information and communication technologies characterized by automation and digitization of the work system. The fourth industrial revolution is marked by the emergence of supercomputers, smart robots, driverless vehicles, genetic editing and the development of neurotechnology that allows humans to further optimize brain function, bringing physical systems and cyber systems together in which all machines are connected to the cyber world, which will radically change the way humans living, working and communicating, and are accessible, smart, simple, time saving, and accurate [4-6]. 
Industry 4.0 is one of the future projects of High Tech Strategy 2020 action plan which was first announced in Germany in 2011 [7]. The goal is to improve the production efficiency and flexibility through a decentralized automation and digitization control system through a real-time controlled value chain [8]. Since its emergence in 2011, industry 4.0 has become a necessity as well as a challenge for the education world, especially for vocational education in preparing professional workers. The industry 4.0 is referred to as a "smart factory" that puts an internetcontrolled virtual system forward with a technological term 'the Internet of Things (IoT)" manifested in data transformation, and automatic and digital technology [9-11]. The industry 4.0 is built on three previous technological transformations: steam power technologies developed in the 19th century, electricity development in the 20th century, and the early computers era in the 1970s [12]. In the industry 4.0, horizontal and vertical relationships exist between machine and the internet, machine and man and machine and machine along the value chain in the real time into a harmonic relationship [13].

It cannot be denied that currently, the SMK is in the era of the fourth industrial revolution. The labour efficiency trends of human labour are replaced by machine automation and robotics systems. The workplace of the genius robots system works through computer automation programs that can work on complicated jobs and have the ability to exchange information. Information technology work system that is characterized by the use of online computer network technology, market transactions both goods and services online is a hallmark of the era of the fourth industrial revolution. In short, in the industrial manufacturing process, if all the work processes are controlled by an online computer network, it can be said that the industry is already based on the fourth industrial revolution.

As a formal education that produces graduates ready to work according to their field of expertise, SMK is required to make alignment with the progress of the fourth industrial revolution era. According to Durmus [14], the existence of industry 4.0 is inevitable, and therefore, SMK should immediately update the curriculum and laboratory facilities of its practice and adapt to industry 4.0. the revitalization of SMK according to Presidential Instruction No. 9 of 2016 should encourage SMK to immediately prepare itself, such as 1) to align the curriculum with the competencies needed by the laboring world (learning method, learning media, and competency assessment system); 2) to increase the teachers' competence with various trainings and apprenticeship in the industry/business world; 3) to alert the quality of the institution; and 4) to enhance the cooperation with ministries/agencies, local governments, and business/industry (DUDI), including competency tests involving industry, course institutions, and professional institutions.

Government Regulation No. 17 of 2010 article 76 paragraph 2 states that the function of SMK, are e.g.: (1) to improve, live and practice the values of faith, noble character, and noble personality; (2) to equip the learners with scientific and technological skills and vocational skills of the professions in accordance with the needs of the community. Meanwhile, to maintain the quality and quality of SMK graduates, the National Education Standards Agency (BSNP) has determined 8 National Education
Standards (SNP), one of them is the graduate competency standard. The graduate competency standards that have been widely studied should be able to meet the output, outcomes (work / further study), and impact in the workforce/industry. In fact, the quality of the labours graduated from SMK, according to Hanafi in Haryana [15] is still lower compared to high school graduates. World Bank study findings indicate that nationally, the average soft skill of SMK graduates is under that of high school graduates. This condition encourages the development of the strategic plan by The Ministry of Education and Culture of 2015-2019. The contents are e.g. the need to apply the Indonesian National Qualification Framework (KKNI), Indonesian National Work Competence Standards (SKKNI), and the demand to strengthen the academic skills for vocational students so they can meet the basic skills that are needed by the industry [15].

\section{THE TEACHING AND LEARNING IN THE SMK WHICH ARE BASED ON THE REQUIREMENT OF THE INDUSTRY WORLD}

To improve the quality of SMK graduates, the learning process is a must. Strategic steps that can be done are to implement the link and match- based education. We need a scenario to implement the educational system that involves the synergy between schools and industry. Schools are a place for educating students and shaping their knowledge, attitudes and basic skills and expertise, and act an industry of partner institutions that form advanced work skills. In schools, the students need to be equipped with strong soft skill values by involving the lecturers and training programs to instil soft skill values. Besides that, students should be also equipped with knowledge and skills in English and Mandarin, as well as a computer. The last is to deepen the learners' skills based on their areas of expertise. The deepening of soft skill values includes communication, honesty, discipline, self-awareness, motivation, teamwork, leadership, adaptation, and problem-solving. The cultivation of these values is carried out during the learning process at school either in class or through independent or group field works. Teachers involved in instilling the soft skill values are the Citizenship and Religion Subject teachers, selfdevelopment trainers, and ESQ trainers with a national reputation. The implementation scenario refers to the principle of reflective learning.

The soft skill values can be taught by integrating two subjects in SMK: citizenship and religion subjects. However, the trainers are not limited only from these two subjects. Through reflective learning methods, the soft skill values will be experienced by learners. Learners are invited to explore each value by using reflective questions including what, why, and how. Reflective learning places students as learning subjects who are always thinking actively and working using their cognitive, affective and psychomotor domains [16]. After implementing this, learners can get a meaningful learning experience for their attitudes. Because during students studying in the vocational education, they are introduced to the character values and they practice them in school, when entering the industrial world, learners have already had the experience of facing the challenges that they likely find. Values of responsibility, honesty, cooperation, tolerance, self-awareness and problem-solving skills are not taught but are instilled in schools through mentoring and the election of school's character values ambassador, either in class or school level. The description of the proposed support skills in school can be seen in Figure 1 below: 


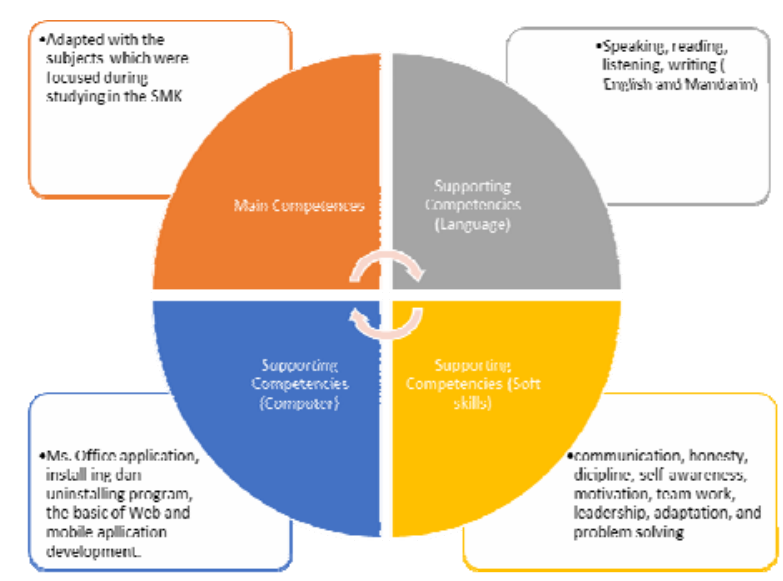

Fig. 1. Main skill and supporting expertise proposed in certification of Vocational Graduate Skills

Once the above values trained and instilled in a school environment with the assistance of experienced trainers, they will be able to shape students' social and spiritual attitudes. At the end of the character building, learners will be given the opportunity to take an attitude competency test by establishing a team-coordinated humanitarian activity that begins by identifying social needs. Each group that will be formed consists of 6-7 people and will be obliged to make a social activities proposal to train and practice their affection values. The final outcome of the humanitarian project activities will be presented and assessed in front of trainers and teachers. The final result is that learners will get an affection competency assessment that refers to an attitude assessment as in the curriculum 2013. The result of affective competence assessment will be reported in a certificate signed by the school leader together with the trainer with self-development training certification. The learner competence is an indicator that he/she has fulfilled the required competencies to be ready to enter the workforce.

Another skill is foreign language mastery that includes Mandarin and English. English mastery includes 1) speaking, 2) reading, 3) listening, and 4) writing skills. Mastering these four skills could become a major competence enhancement for the learner. The English speaking training coordinator can be the English teachers in cooperation with some teachers from English courses such as Briton, EF English First, and other English language institutions that have certified in language training. Learning activities can be done by integrating them into English lessons and arranging additional learning programs after the main English class. This activity can be conducted during one semester by employing the constructivist English learning models. It is also a good idea to regulate all students to use English in school to establish English speaking culture. This effort will support the learners to get a competence in English. At the end of the English learning program, we can provide English competency certification after the students followed a series of English learning and activities every Saturday, both at school and outside the school. To further improve the quality of the English learning system, we can pioneer partnerships between schools and language institutes under the Ministries of Education and Industry so that the legitimacy of the cooperation is more mutually reinforced.
The same approach applies to the certification of Mandarin skill. By working with a Chinese language course, schools can plan Chinese language learning programs at school. Teaching Mandarin is focused on: 1) the Mandarin pronunciation, 2) the daily conversation, 3) numbers, and 4) basic words. The learning model that can be applied is the constructivist approach that allows learners to be more creative. The tutor could come from a certified Chinese language course institution that enables learners to obtain competence certificate on Mandarin. The basic computer skill is also a supporting competency that gives a plus for the vocational learners (especially for learners who are not majoring computer). The basic computer skills trained include: 1) introduction of MS. Office (word, excel, ppt, and access), 2) web development, 3) computer installations, and 4) mobile apps. These four competencies are the basic competencies required for students to compete in the era of industrial revolution 4.0. Computer training can involve ICT teachers partnering with computer course institutions that have been certified.

\section{Test MOdel of COMPETENCY-BASEd PARTNERShiP CERTIFICATION TEST}

To meet the standardization of competency skills of vocational school students, we will conduct competency certification tests or competence skills test (UKK). This test will measure students' practical skills before graduating. According Damarjati [17], the implementation of the UKK aims to measure the student competence achievement at a certain level according to the skill competence undertaken during studying in SMK. Graduates require not only the core competency skills that are in accordance with their own scientific heresy, but also other supporting competencies such as language skills, problem solving skills, and computer skills. These capabilities are often required by the industry to support the graduate's core competency. The material tested will be in accordance with the areas of the students' expertise, including the vocational theory and practice. Vocational theory measures the learners' mastery on the basic knowledge, analytical thinking, reasoning, and problem analysis and solving. Vocational practice measures the learner's ability to do project tasks with the right working steps to produce the right and precise product [18]. The materials of competency test are the main competencies that should be mastered by the students after graduating from vocational school. We need to include language skills (English and Mandarin), computer skills, and soft skill as supporting competencies and provide certification on them. The party certifying the profession will be an institution with a national credibility and professional qualification in conducting competency assessments. This institution will be the Professional Certification Institute (LSP) established by industry associations and/or professional associations with the aim of implementing competence certification for certain sectors and/or professions in accordance with the scope given by the National Agency for Standardization of Professionals (Bakrun, 2018). Therefore, the certification body should consist of licensed assessors from DUDI, from LSPP1 member schools (established by BNSP) and LSPP2 (established by provincial service), from national language and computer language courses, and soft skill trainers).

The competency certification model of each proposed expertise may refer to one of the competency certification test models that PSMK already delineates. According to 
Bakrun (2018), there are four models of skill competency test implementation which are: 1) UKK works in partnership with institutions, business world and industry (DUDI) or Professional Association; 2) UKK is held by the First Learner Professional Certification Institution (LSPP1) -SMK licensed by BNSP for learners of central SMK and other SMKs included in the LSPP1-SMK network; 3) UKK is organized by the Secondary Profession Certification Institute (LSPP2) established by the Provincial Education Office licensed by BNSP with a certification scheme for SMK; and 4) UKK is organized by Third Professional Certification Agency Party(LSPP3) licensed by BNSP and has a certification scheme for SMK.

The first undertaken stage of this proposed model creating a partnership with particular institutions, either from: 1) business / industry, professional associations; 2) language course institutions; or 3) a standardized skill training institution (soft skill). These three institutions can conduct a joint learning. The next step will be the competency certification test that refers to the principles of assessment of competence test skills, both key skills and supporting skills such as language, computer, and soft skills. The scenario of the skill competency test can be seen in Figure 2 below:

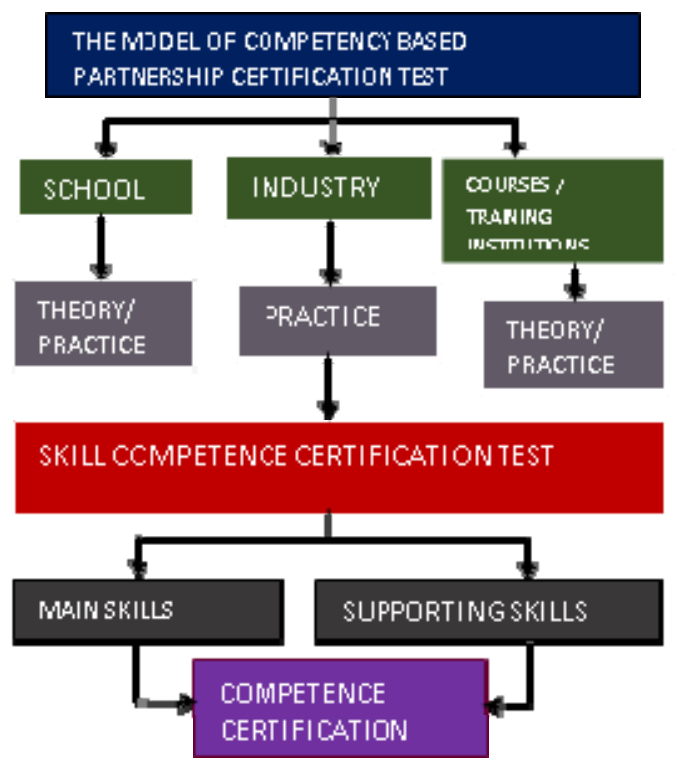

Fig. 2. Main skill and supporting expertise proposed in certification of Vocational Graduate Skills

Based on the competency test model in Figure 2, the role of each institution can be explained as follows:

\section{A. School}

In skill competency tests, the learning process in school will take place based on the constructivist learning principles. Schools play a role in conducting learning activities in addition to basic vocational practice learning. The competence grant will be based on the curriculum of each applicable course. School is expected to organize a learning system that emphasizes the independence of learners in learning, solving vocational problems, and cooperating in study groups. Schools continue to conduct regular semester exams based on the instructional evaluation guidelines. Schools play a role in planning the high-quality learning, and implementing and evaluating the plan in accordance with national education standards. School in this case, is the place of knowledge and skills formation based on minimum standards of competence of each course.

\section{B. Industry}

The existence of industry in the proposed model of expertise competency is as a school assistant focusing on the introduction and in-depth of applicative skills aspects required in the industry. The industry and the school work in a partnership in designing the basic skills and advanced skills needed in the industry. Together with schools and industry, they design a curriculum that contains the technical competencies required in the era of industry 4.0. According to Durmus [14], a number of knowledge and skills required in the era of industry 4.0 include an understanding of data analysis, computer software, cybersecurity systems, robotic applications, and digital process systems.

\section{Course / Training Institution}

The existence of the course institution in accelerating the learners' knowledge and skills transfers in the era of industrial 4.0 can provide knowledge of theory and practice in the fields of language, computer and soft skills. In the field of language, professional coursework institutions can work with schools to arrange language courses during the planned time frame. Languages competences which will be trained include: speaking, reading, listening, and writing. Computer fields include web application development and mobile apps. Both of these competencies are relevant to the era of industrial 4.0 needs. Competency that is trained includes soft skill for students' self-development. A number of soft skill required in the era of industry 4.0 are e.g.: learning motivation, problem solving, cooperation, teamwork, adaptability on changes, and agility [14]. In this paper, the recommended soft skills are: communication skills, teamwork skills, problem solving skills, leadership, adaptability, and honesty. The overall competences that will be trained are the the main and supporting competencies. The course / training is conducted during the learning process, and planned and implemented with reference to the curriculum of each skill.

\section{The Certification Competency Test (Main and Supporting)}

After taking education in SMK level, students are expected to have two competencies: the main competencies and supporting competencies. The main competencies will be tested by competence certification bodies authorized by either LSPP1-SMK, LSPP2, or LSPP3 which are licensed by BNSP. Supporting competencies will be certified by professional coursework institutes which have a reputation in organizing courses both nationally and internationally.

The skills competency test scheme formulated in chart 2 above demonstrates the involvement of business/industry sectors, course institutions, and self-development (such as soft skills) training institutions as partner institutions that provide the supporting skill training. Supporting expertise is an addition of key skills. These skills include computer skills, English skills, Mandarin skills, and soft skill. English skills may include: speaking, reading, listening, and writing. 
Mandarin skills include Chinese language pronunciation, daily conversation, numbers, and basic words. Computer capabilities include the application of Ms Office (word, excel, powerpoint, access), the program installation and uninstallation, basics web development, and mobile apps. This competence is considered as a new literacy consisting of data literacy, technological literacy, and human literacy. Data literacy is the ability to read, analyze and make conclusions based on data and information (big data). Technology literacy is the ability to understand the work of machines, technology applications and work-based technology products to get the best outcomes. Human literacy is the ability to communicate, collaborate, think critically, be creative and innovative [19]. The scores of the main competencies written in the competency test certificate indicate that the graduates are ready to work.

\section{CONCLUSION}

The competence certification for SMK graduates will be conducted by portraying two types of competencies, which are: 1) the main competence in accordance with the area of expertise instilled, and 2) supporting competence that includes computer skills, language skills (English and Mandarin), and soft skills. Those skills will be tested by involving a partnership pattern between a reputable school, business/industry, and course institution. The implementation mechanism of skill competency test can refer to a model organized in cooperation between the business/industrial world (DUDI) and Professional Association.

\section{ACKNOWLEDGMENT}

The authors would like to thank the National and International Seminar Committee of APTEKINDO 2018 University of Surabaya (UNESA) which has organized this event and accepted this article to be published as a reading material in the proceedings under vocational technology education topics

\section{REFERENCES}

[1] Rousseau, J. J. (1991). Emile: or On Education, trans. Allan Bloom London: Harmondsworth: Penguin Books

[2] Direktorat Pembinaan Sekolah Menengah Kejuruan Direktorat Jenderal Pendidikan Dasar dan Menengah Kementerian Pendidikan dan Kebudayaan (2018), Panduan Pelaksanaan Uji Kompetensi Keahlian. Jakarta

[3] Dhakiri, M. Hanif. 2017. Persaingan Kian Ketat, Saatnya Tingkatkan Kompetensi Tenaga Kerja. http://news.liputan6.com/read/2933831/persaingan-kian-ketat- saatnya-tingkatkan-kompetensi-tenaga-kerja. Accessed 20 March 2018

[4] Schwab, Klaus. 2016. The Fourth Industrial Revolution. World Economic Forum:Switzerland

[5] Kamdi. Waras. (2017). Revitalisasi SMK untuk Menjawab Tantangan Revolusi Industri 4.0 http://mondayreview.com/artikel/detail/3305/revitalisasi-smk-untukmenjawab-tantangan-revolusi-industri-40. Accessed 12 March 2018

[6] Kasali, Rhenald. (2017). Disruption. Gramedia Pustaka Utama:Jakarta

[7] Kagermann, H., Wahlster, W., Helbig, J. (2013). Recommendations for implementing the strategic initiative Industrie 4.0. Report, Industry 4.0 Working Group

[8] Prifti, L.; Knigge, M.; Kienegger, H.; Krcmar, H. (2017): A Competency Model for "Industrie 4.0" Employees, in Leimeister, J.M.; Brenner, W. (Hrsg.): Proceedings der 13. Internationalen Tagung Wirtschaftsinformatik (WI 2017), St. Gallen, S. 46-60

[9] Dutton, H.W. (2014). Putting Things to Work: Social and Policy Challenges for the Internet of Things. Info, 16(3): 1-21. https://doi.org/10.1108/info-09-2013-0047.

[10] Buhr, D. (2015). Social Innovation Policy for Industry 4.0. Tübingen, Germany: Eberhard Karls University of Tübingen.

[11] Morrar, R., Arman, H., \& Mousa, S. (2017). The Fourth Industrial Revolution (Industry 4.0): A Social Innovation Perspective. Technology Innovation Management Review, 7 (11): 12-20. http://doi.org/10.22215/timreview/1117.

[12] Cordes, F., \& Stacey, N. (2017). Is UK Industry Ready for the Fourth Industrial Revolution? Boston, MA: The Boston Consulting Group.

[13] Yu, C., Xu, X., and Lu, Y. (2015), “Computer-Integrated Manufacturing, Cyber-Physical Systems and Cloud Manufacturing Concepts and relationships", Manufacturing Letters, 6, pp. 5-9.

[14] Durmus, Ali and Dagli, Abdulkadir, (2017). Integration of Vocational Schools to Industry 4.0 by Updating Curriculum and Programs, International Journal of Multidisciplinary Studies and Innovative Technologies. 1 (1): 1-3.

[15] Haryana, Kir. (2014). Pengelolaan dan Penyelenggaraan Sekolah Menengah Kejuruan (SMK) di Indonesia. Disampaikan dalam Seminar "Refleksi Kritis Kebijakan Pendidikan Nasional dan Daerah" yang diselenggarakan oleh Program Studi Kebijakan Pendidikan, Fakultas Ilmu Pendidikan, Universitas Negeri Yogyakarta pada Tanggal $30 \quad$ April 2014. staff.uny.ac.id/sites/default/files/pendidikan/slamet-ph...dr.../2kebijakanok.pdf. Accessed 18 March 2018

[16] Aryani, Farida. Rais, Muhammad. Wirawan, Hilman. 2017. Reflective Learning Model In Improving Student Critical Thinking Skills. GJEE. Volume 19, Number 1, 2017. Accessed 16 March 2018

[17] Damarjati, Taufik. 2016. Uji Kompetensi Keahlian Final. https://psmk.kemdikbud.go.id/konten/2143/uji-kompetensi-keahlianfinal. Accessed 15 March 2018

[18] Bakrun, M. (2018). Panduan Pelaksanaan Uji Kompetensi Keahlian. Direktorat PSMK Direktorat Jenderal Pendidikan Dasar dan Menengah Kementerian Pendidikan dan Kebudayaan. Jakarta

[19] Rozak, Abd. 2018. Perlunya Literasi Baru Menghadapi Era Revolusi Industri 4.0. http://www.uinjkt.ac.id/id/perlunya-literasi-barumenghadapi-era-revolusi-industri-4-0/. Accessed 15 March 2018 